\title{
多年次衛星データを利用した草地更新状況の把握
}

\section{Monitoring Grass-Renovation Status using Multi-Temporal Satellite Data}

\author{
美濃伸之*, 斎藤元也* \\ Nobuyuki MINO, Genya SAITO
}

\begin{abstract}
Once grassland productivity decreases, grass-renovation, accompanied by plowing and seeding, needs to be conducted to improve its productivity. Years after grass-renovation is one index indicating grassland productivity. In this study, the monitoring of grass-renovation status using satellite data is discussed. By extracting 1-year grassland and renovated grassland from each satellite image, we compiled a Grass-renovation years map (1985-1994). Renovation years from satellite data agreed with that from ground survey with high accuracy, showing that satellite remote sensing is very useful for survey of grass-renovation status.
\end{abstract}

\section{1.はじめに}

草地を全面的に耕起し，再播種を行う草地更新は， 牧草収量の低下, 草種構成の劣化が著しい場合に，そ れらの改善を四る目的で行われる。草地更新後の年数 を示す経年数は，草地の少化程度を把握するための一 つの重要な指標であり，草地管理上，不可久な情報で ある。

現在, 草地更新の宇態は, 部分的には帳簿や報告書 の形で記録されているが，その把握には多くの労力を 必要としている。これらの情報形態では, 地理的分布 に関する情報が欠落していること，情報が分散してお り，記録形態も様々である等のことから，実際に，ど この草地がいつに更新したかを調べることは容易では ない。また，広域におよぶ草地更新の実態は十分把握 できていない場合が多い。したがって，広域の地理的 分布を含む草地更新の現状を示すマップを作成するこ とができれば，様々な草地管理の場面に有益である。

広域情報が得られる衛星リモートセンシングの技術 は, 農業分野における有効性が, 多くの報告により示

*農業環境技術研究所

* National Institute of Agro-Environmental Sciences

3-1-1 Kannondai, Tsukuba, Ibaraki, 305, JAPAN

「写真測量とリモートセンシング」VOL. 35, NO. 3, 1996
されている7)。その中でも，草地は，その圃場面積が広 いことや地上バイオマス自体が収穫量に結びつくなど の特性により, 比較的早い時期から, 衛星リモ一ト七 ンシングに関する研究の対象となった(1),2),3),4),5),6),11)。

研究報告としては, 各種衛星デ一タから植生指数等 のバイオマスに関する指標を算出し, 収量や荒廃状況 を推定した例が多い。しかし，草地の経年数や更新状 㳘などの草地管理に関連する情報を衛星デー夕から捉 えた報告はほとんどない。筆者らは，草地の経年化に 伴う分光反射特性の変化を多年次衛星デー夕を利用し て解析し，既に報告した(以下では前報とする) ${ }^{10)}$ 。本 研究では, 前報の経年数別の草地分光反射特性を利用 して草地更新状況の把握を行ったので報告する。

\section{2. 研究方法}

\section{(1) 解析方針}

草地更新は全面的な耕起を伴う。そのため, 更新草 地の地表面には, 耕起直後から1力月程度まで, 他の草 地において牧草量が豊富な時期に土壤が露出してい る。また, 収穫後の草地の地表面には, 枯死した植物 体等が集積しており, 土壌は露出していない。そのた め, 更新草地は, 収穫前の草地や収穫後の草地と明確 に区別できる。

筆者らは前報で, 多年次衛星デー夕から更新草地を 
抽出し、それらと衛星デー夕を重ね合わせることによ り, 各草地の経年数を把握, 経年数別の草地分光反射 特性を調べ報告した。多年次衛星デー夕から更新草地 を抽出した更新年次基準四は, 当該年次に更新した草 地のうち, 衛星デー夕観測以後に更新した草地は検出 ができていない。また, 衛星デー夕観測日より1ケ月程 以前に播種をした草地も牧草が生育し, 土堙が露出し なくなるため, 検出が難しい。

本研究では, 図1に示すように, 草地更新の検出を行 う際に, 更新草地の抽出に加えて, 前報で明らかにし た経年数別の草地分光反射特性を利用し, 翌年のデー 夕で当該年次の観測日以後の草地更新を追加して, 検 出することとした。前報より, 新播草地（経年数1年） が他の経年草地と比較して, 明確な特徵を持つことが 示されている。そのため, ここでは, 衛星データより 更新草地, 新播草地を検出, 新播草地と判別されたも のは, 衛星デー夕取得年の前年に草地更新を行った草 地とみなし，1985年から1994年までの草地更新を検出 した。また, 各年次毎に作成した草地更新マップを全 て重ね合わせて, 1994年5月現在での各草地の更新年次
を示すマップを作成した。

\section{（2）対象地域と使用衛星デー夕}

本研究では, 北海道根釧地域を対象とした。根釧地 域は夏期にも泠涼で, 草地酪農に適しており, 農地面 積の約 $97 \%$ が草地である。

解析には，1985〜1994年までの, LANDSAT/TM, MOS-1/MESSR, JERS-1/SAR の各衛星デー夕を使 用した。本研究で使用した衛星デー夕を表 1 にまとめ た。対象地域での草地更新は，春先から夏にかけて不 定期に行われるため, 各年次毎に4月から8月の LANDSAT/TM, MOS-1/MESSR デー夕を可能なかぎり 収集し, 更新草地を検出するのに利用した。新播草地 を抽出するのには, 前報で経年数別の草地分光反射特 性を調べた5月および6月の LANDSAT/TM デー夕 を利用した。また, JERS-1/SARデー夕は, 森林領域 の抽出に利用した。

\section{（3）衛星データ前処理}

衛星データの精密幾何補正は，1989年5月19日の

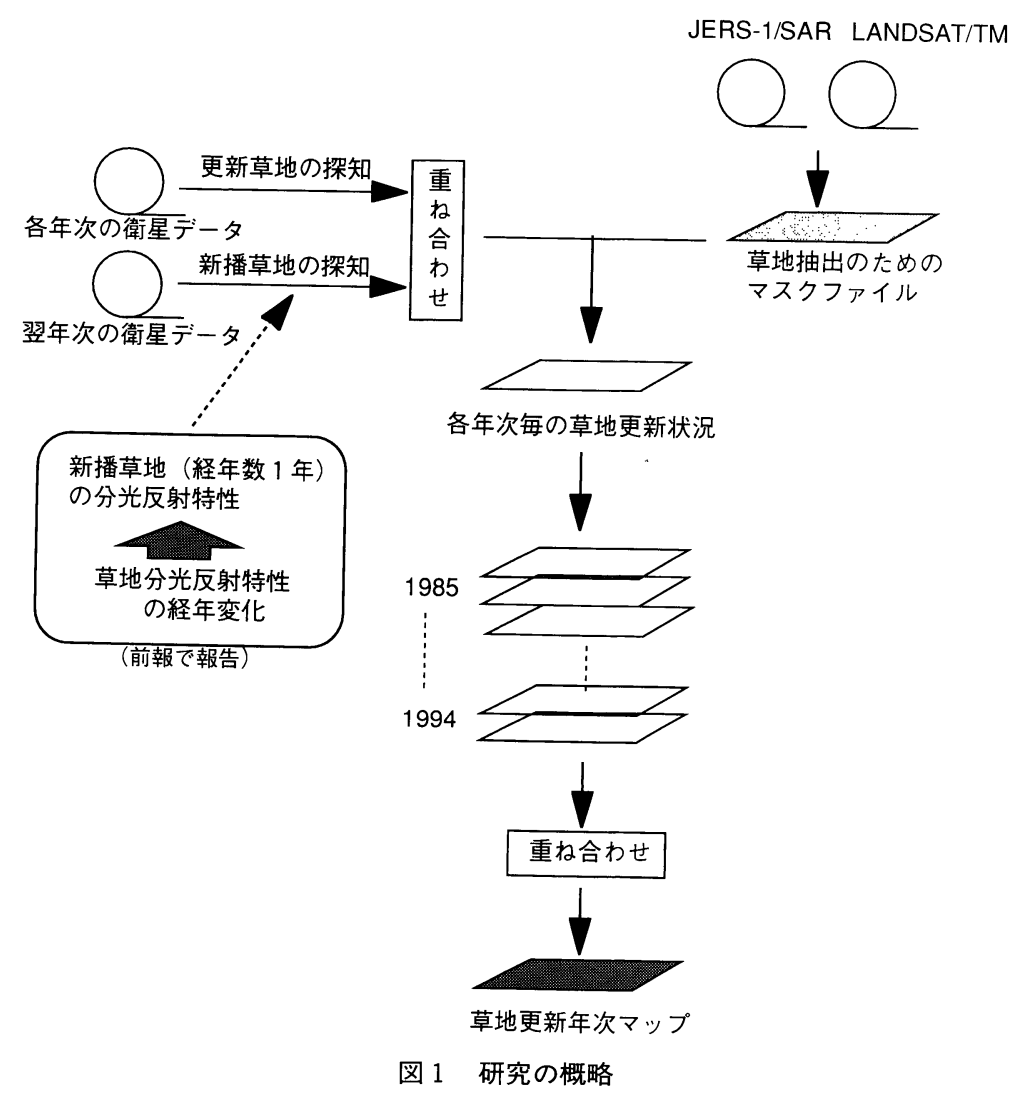


表 1 使用衛星データー覧

\begin{tabular}{|c|c|c|c|c|c|}
\hline パスーロウ & センサ & 観測日時 & パスーロウ & センサ & 観測日時 \\
\hline $106-30$ & TM & 85.05 .24 & $106-30$ & $\mathrm{TM}$ & 91.04 .23$. \\
\hline \multirow[t]{2}{*}{$106-30$} & TM & 85.07 .27 & $106-30$ & $\mathrm{TM}$ & 91.06 .26 \\
\hline & & & $106-30$ & TM & 91.08 .29 \\
\hline $106-30$ & TM & 86.06 .28 & & & \\
\hline \multirow[t]{2}{*}{$106-30$} & TM & 86.07 .30 & $105-30$ & TM & 92.04 .09 \\
\hline & & & $106-30$ & TM & 92.06 .28 \\
\hline $105-30$ & TM & 87.05 .07 & $105-30$ & TM & 92.08 .24 \\
\hline \multirow[t]{2}{*}{$19-59 \mathrm{E}$} & MESSR & 88.06 .06 & $105-30$ & TM & 93.04 .21 \\
\hline & & & $105-30$ & $\mathrm{TM}$ & 93.06 .08 \\
\hline $105-30$ & TM & 89.05 .19 & & & \\
\hline $105-30$ & $\mathrm{TM}$ & 89.06.13. & $105-30$ & TM & 94.05 .17 \\
\hline \multirow[t]{2}{*}{$19-59 \mathrm{E}$} & MESSR & 89.08 .22 & & & \\
\hline & & & $59-227 \mathrm{JH}$ & ERS-1/SAR & R 92.4.15. \\
\hline $106-30$ & $\mathrm{TM}$ & 90.04 .20 & $59-228 \mathrm{JH}$ & ERS-1/SAR & R 92.4.15. \\
\hline $106-30$ & $\mathrm{TM}$ & 90.06 .07 & & & \\
\hline $105-30$ & TM & 90.07 .02 & & & \\
\hline $105-30$ & $\mathrm{TM}$ & 90.08 .03 & & & \\
\hline
\end{tabular}

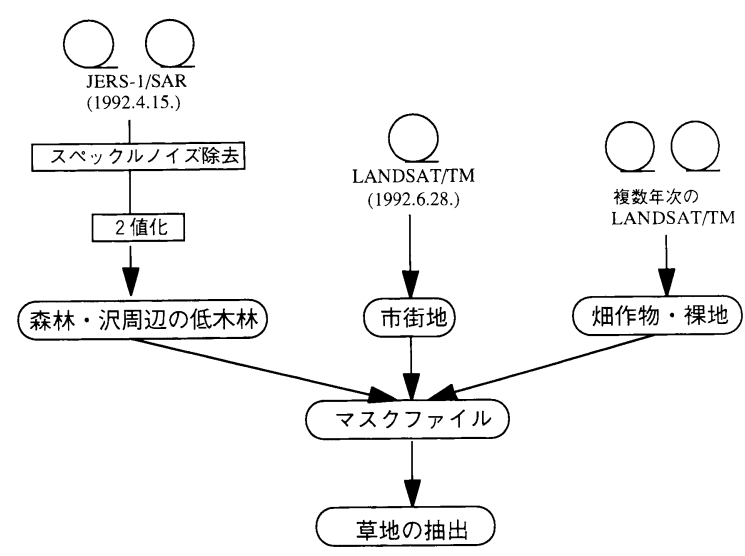

図 2 マスクファイル作成の概略

LANDSAT/TM のみ, 1/50,000地形図を用いて行い, 1画素の大きさは $25 \mathrm{~m} \times 25 \mathrm{~m}$ とした。残りのシーンは， この幾何補正済みの LANDSAT/TM データを基準 として，画像間で幾何補正を行った。

草地更新状況を把握した範囲は，およそ $1 / 50,000$ 地 形図の中標津, 計根別の範囲に相当し, UTM 座標系の ゾーン番号55带で, 左上隅 $(318,621.06$, $4,836,822.50)$, 右下隅 $(343,310.66,4,799,173.00)$ と した。

\section{3. 解析結果}

\section{（1）草地の抽出}

対象地域内には草地の他に, 森林, 市街地, 畑作地 が分布する。草地更新状況の把握には，これらを除去 し，草地のみを解析する必要がある。そのため, 複数 の衛星デー夕を利用して, 森林, 市街地, 畑作地を抽 出し，マスクファイルを作成した。マスクファイル作 成の概略を図2に示す。

森林の抽出には，JERS-1/SAR データを利用した。 JERS-1/SAR データは波長が L バンド $(23 \mathrm{~cm})$ であ り，森林では，幹，枝からの高い後方散乱が得られる。 しかし，牧草のように波長より小さな植被が対象の場 合は，マイクロ波のほとんどが透過してしまうため， 土㙵表面からの低い後方散乱のみを示す。SAR 画像上 では，スペックルノイズと呼ばれるゴマ塩状のランダ ムなノイズが存在するため, ここでは MAPフィル 夕99)利用して除去した。その後, 地形図を参照しなが ら閾值を決め, CCT 值の高い部分の森林を抽出した。 この森林として抽出した部分には, 市街地も一部含ま れていた。

市街地の抽出には，1992年6月28日の LANDSAT/ TM データのバンド1とバンド5を用いた。閾值は地形 図で市街地の地点の CCT 值を参照しながら決定し， バンド $1>90$, かつバンド $5<110$ の領域を市街地とし た。またここの時期に飼料用のトウモロコシ畑はビニー ルマルチをしていることが多く, 市街地と同様の分光 仅射を示すために，同時に抽出された。

バレイショを中心とした畑作地は，4月から6月上旬 にはまだ土壌が露出している。従って, 多年次にわた り, この時期に土壤が露出している領域は畑作地とし て抽出した。各衛星データにおいて土㙵が露出してい ると判断した基準は，(2)での更新中の草地を探知する 際の基準と同じとした。畑作地の位置は年次毎に異な るため, 衛星デー夕取得に制限がない限り, 当該年次 とその後年の衛星デー夕を利用して，各年次毎に畑作 地の抽出を行った。

以上のようにして, 森林, 市街地, 烟作地を抽出し, 草地を 1 ，それ以外を 0 としたマクファイルを作成し た。畑作地の位置が年次毎に異なるため, マスクファ イルはそれに応じて作成した。 


\section{（2）更新草地，および新播草地の検出}

更新草地は, 衛星デー夕上で植生量が少なく, 全体 の分光反射も低い領域と定義し, 各シーンから抽出し た。ここでは，NDVIを指標に低植生領域を抽出した 後, 可視, 中間赤外, 熱赤外の CCT 值を利用して, 雲 域，雲影，収穫後の草地を除去し，残った領域を更新 草地とした。NDVI, 各バンドの閾値は, 衛星デー夕の 観測日時や地形図を参照しながら決定した。各シーン 毎の閾値を表 2 にとめた。

新播草地の抽出の際には，筆者らが前報で明らかに した分光反射特性を利用した。 5 月，および 6 月に観測 された衛星デー夕における新播草地の分光反射特性に ついては前報を参照されたい。新播草地は，5月の LANDSAT/TM 上では, 他の経年草地と比較して, 全 体に分光反射強度が低い特徵を持つ。また，6月の LANDSAT/TM 上ではバンド4とバンド5の分光反射 強度が極めて高いという特徵を持つ。しかし，5月の衛 星デー夕においても，6月の衛星デー夕においても，2 年目や3年目の草地は, 新播草地と分光反射特性が似 通っている。そのため, 新播草地の各バンドの平均值士 標準偏差に相当する領域を各衛星デー夕から抽出して
きた場合には， 2 年目や 3 年目の草地との誤判読が多く なってしまう。そこで，新播草地を抽出する際には， 5 月の衛星データでは, 平均值よりも CCT 值が高い領 域の閾值を厳しくし，また，6月の衛星データでは，平 均值よりも CCT 值が低い領域の閾值を厳しくし，2年 目以降の草地との誤判読を防ぐこととした。

1986，1989，1990，1991，1992，1993年の年次に関 しては, 最も新播草地の特徵が明確になる6月の LAN $\mathrm{DSAT} / \mathrm{TM}$ デー夕を使用した。6月の衛星データにお いては，そのバンド4，バンド5の平均值，および標準 偏差を利用し，以下の CCT 值の範囲を新播草地とし て抽出した。

$$
\mu_{1}-\frac{1}{2} \sigma_{1}<\widehat{\mu}_{1}<\mu_{1}+2 \sigma_{1}
$$

ここで, $\mu_{1}$ は前報で算出したバンド 4, およびバンド 5 の の平均值， $\sigma_{1}$ は，その標準偏差を示し，バンド4, バン ド5の両方が条件を満たす場合を新播草地とした。

また1994年は5月のデー夕を利用して,新播草地の抽 出を行った。5月のデー夕においては, 経年変化把握の 際に明らかにした新播草地のバンド 3 ，バンド 4 , バン ド5の平均值，および標準偏差を利用し，以下の CCT

\section{表 2 各衛星データにおける更新中の草地を探知する際の基準}

\begin{tabular}{|c|c|c|c|c|}
\hline 衛星データ & 低植生領域の抽出 & \multicolumn{2}{|c|}{ 雲影、および収穫後草地の除去 } & 雲域の除去 \\
\hline 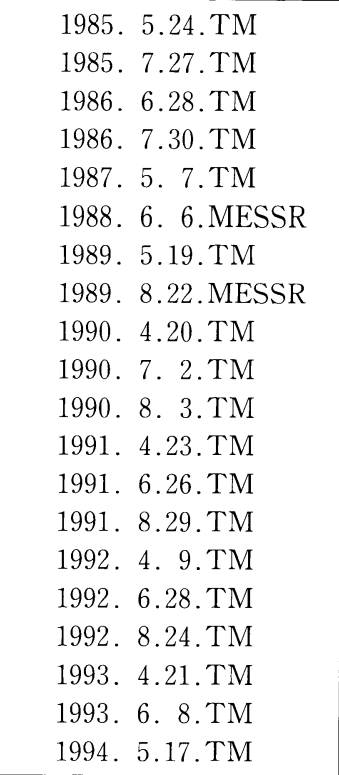 & $\begin{array}{l}\text { NDVI }<0.1 \\
\text { NDVI }<0.45 \\
\text { NDVI }<0.5 \\
\text { NDVI }<0.5 \\
\text { NDVI }<0.1 \\
\text { NDVI }<0.05 \\
\text { NDVI }<0.05 \\
\text { NDVI }<0.1 \\
\text { NDVI }<0.05 \\
\text { NDVI }<0.5 \\
\text { NDVI }<0.4 \\
\text { NDVI }<0.05 \\
\text { NDVI }<0.5 \\
\text { NDVI }<0.4 \\
\text { NDVI }<0.05 \\
\text { NDVI }<0.4 \\
\text { NDVI }<0.5 \\
\text { NDVI }<0.05 \\
\text { NDVI }<0.4 \\
\text { NDVI }<0.1\end{array}$ & $\begin{array}{l}\text { BAND1 }<95 \\
\text { BAND1 }<85 \\
\text { BAND1 }<90 \\
\text { BAND1 }<85 \\
\text { BAND1 }<95 \\
\text { BAND1 }<18 \\
\text { BAND1 }<85 \\
\text { BAND1 }<17 \\
\text { BAND1 }<70 \\
\text { BAND1 }<75 \\
\text { BAND1 }<75 \\
\text { BAND1 }<70 \\
\text { BAND1 }<70 \\
\text { BAND1 }<65 \\
\text { BAND1 }<90 \\
\text { BAND1 }<85 \\
\text { BAND1 }<70 \\
\text { BAND1 }<70 \\
\text { BAND1 }<80 \\
\text { BAND1 }<71\end{array}$ & $\begin{aligned} & \text { BAND5 }<140 \\
& \text { BAND5 }<90 \\
& 25<\text { BAND5 }<80 \\
& 55<\text { BAND5 }<80 \\
& 45<\text { BAND5 } \\
& \\
& \\
& \quad \text { BAND5 }<90 \\
& \quad \text { BAND5 }<100 \\
& 55<\text { BAND5 }<90 \\
& 35<\text { BAND5 }<70 \\
& \text { BAND5 }<90 \\
& 50<\text { BAND5 }<85 \\
& \text { BAND5 }<80 \\
& \text { BAND5 }<100 \\
& 50<\text { BAND5 }<80 \\
& \text { BAND }<10 \\
& 60<\text { BAND5 } \\
& 50<\text { BAND5 }\end{aligned}$ & BAND6 $<120$ \\
\hline
\end{tabular}


值の範㖀の領域を新播草地として抽出した。

$$
\mu_{2}-2 \sigma_{2}<\widehat{\mu}_{2}<\mu_{2}+\frac{1}{2} \sigma_{2}
$$

ここで， $\mu_{2}$ は経年数別の草地分光特性を把握した際に

算出したバンド 3 ，バンド 4 ，バンド 5 の平均值， $\sigma_{2}$ は，

その標準偏差を示す。この場合も，バンド 3 , バンド 4 ,

バンド5の全てが,この条件を満なす場合を新播草地と

した。

ただし，1987，1988年の年次は，5月，6月の LAND $\mathrm{SAT} / \mathrm{TM}$ デー夕が取得できなかったため, 新播草地 の抽出は行わなかった。
（3）各年次毎の草地更新状況の把握と1994年5月現在 での草地更新年次マップ (1985～1994)の作成

このように, 抽出した更新草地, 新播草地を重初あ わせて, 各年次每の草地更新マップを作成した。また, 各年次型に, 全草地面積に対して草地更新が行われて いる割合を算出した。さらに, 各年次毎の草地更新マッ プを重ね合わせることにより，1985年から1994年の草 地更新年次マップを作成した。

各年次毎の草地更新状沉は, 当該年の衛星デー夕か ら抽出した更新草地，拉よび装年の LANDSAT/TM

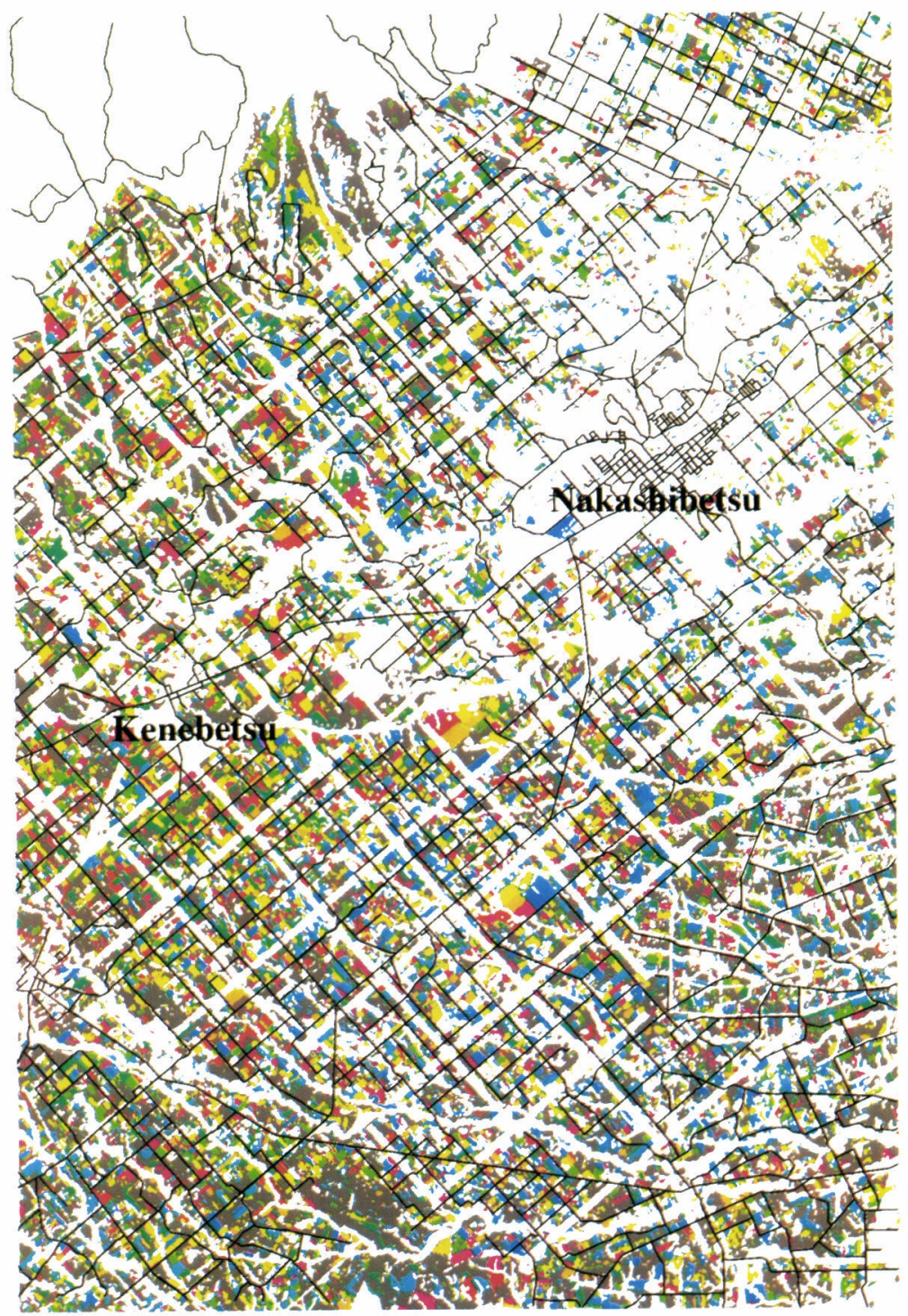

写真 1 草地更新年次マップ (1985-1994)

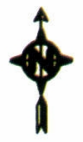

\section{Grass-Renovation Years Map (Konsen Area)}

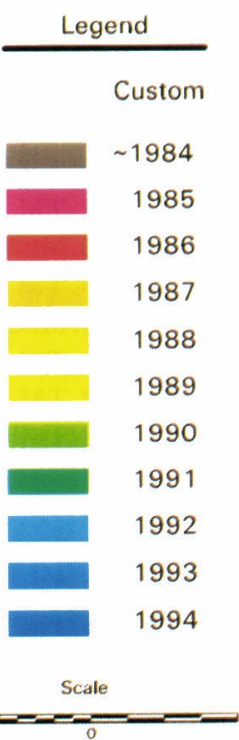


データから抽出した新播草地の分布図を重ね合わせる ことにより把握した。ただし，当該年次の 1 年前に，既 に草地更新を行ったとして抽出されている領域は, 更 新草地分布図, 新播草地分布図から除外した。圃場境 界や戋場の一部に分光反射特性のみでは抽出できてい ない部分があったため, 更新草地，あるいは新播草地 として抽出したピクセルの4近傍も更新草地, あるいは 新播草地であるとした。また, フィル夕処理後に, 各 ピクセル毎の連続程度を評価し, 連続8ピクセル以下の ものは䛊分類として除去した。

草地更新年次マップは, 各年次毎に作成した草地更 新状況を表すマップを全て重ね合わせて作成した。重 ね合わせの際には, 年次の新しい方を優先とした。出 力の際は, 利用価值を高めるため, 主要道路を重ね合 わせ， $1 / 50,000$ のスケールで出力した。草地更新年次 マップを写真1に示す。

\section{4. 考察}

\section{（1）各年次毎の草地更新マップ}

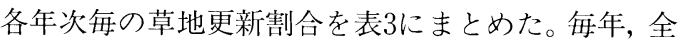
草地の6 8\%程度が更新されているという結果となっ た。ただし, 更新の当該年の衛星デー夕と翌年の衛星

\section{表 3 各年次毎の草地更新状況}

\begin{tabular}{|c|c|}
\hline 年 次 & 草地全体に占める割合 $(\%)$ \\
\hline 85 & 7.8 \\
86 & 6.1 \\
87 & 4.5 \\
88 & 5.7 \\
89 & 9.1 \\
90 & 8.5 \\
91 & 6.2 \\
92 & 6.7 \\
93 & 6.0 \\
94 & 4.2 \\
\hline
\end{tabular}

表 4 衛星データから把握した更新年次と地上データ との一致率

\begin{tabular}{|c|c|c|c|}
\hline & 対象戋場数 & $\begin{array}{c}\text { 聞き取り調査と結果 } \\
\text { が一致した圃場数 }\end{array}$ & 一致率 \\
\hline $\begin{array}{l}\text {-1年のズレを } \\
\text { 許さない場合 }\end{array}$ & 43 & 25 & $58(\%)$ \\
\hline $\begin{array}{c}\text {-1年のズレを } \\
\text { 許した場合 }\end{array}$ & 43 & 35 & $79(\%)$ \\
\hline
\end{tabular}

データの取得に制限のある1987年，1994年は，十分な 草地更新の把握ができなかった。対象地域が位置する 根室支庁管内は，北海道の中でも草地更新を行う割合 が高く, 平均して 7 $8 \%$ の更新率であることが地上調 査により報告されている ${ }^{8)}$ 。衛星デー夕による解析結 果は, 地上調査で報告された更新割合とほぼ一致する ため, 対象地域内に扔ける各年次毎の草地更新のうち, 大部分が衛星デー夕により把握できたと考えられる。

\section{（2）草地更新年次マップの検証}

多年次衛星デー夕を利用して作成した草地更新年次 マップを評価するために, 衛星デー夕から把握した更 新年次と地上調查で調べた更新年次とを比較した。そ の結果を表4にまとめた。それによれば, 完全な一致率 は6割程度で, 衛星データでは実際の更新年次の翌年を 更新年次としてしまうズレが多いことが判った。

根釧地区において, 夏期以降に耕起した草地では, 冬枯れを避け, 株の定着率を高めるために, 翌春に播 種することが多い。それらの草地は，1年目の草地で あっても春先までの状態は耕起直後の草地と変わらな い。それらの草地を衛星デー夕で探知すると，実際は， その前年に耕起をしているが，マップ上では衛星デー 夕の観測年次だとされてしまう。このように, 地上デー タとのズレは耕起年次と播種年次の違いによるものと 推測された。このズレを許容すると地上調査との一致 率は8割程度となった。この更新年次の地上調査は農家 に対して，聞き取り調查で行われた。しかし，これら

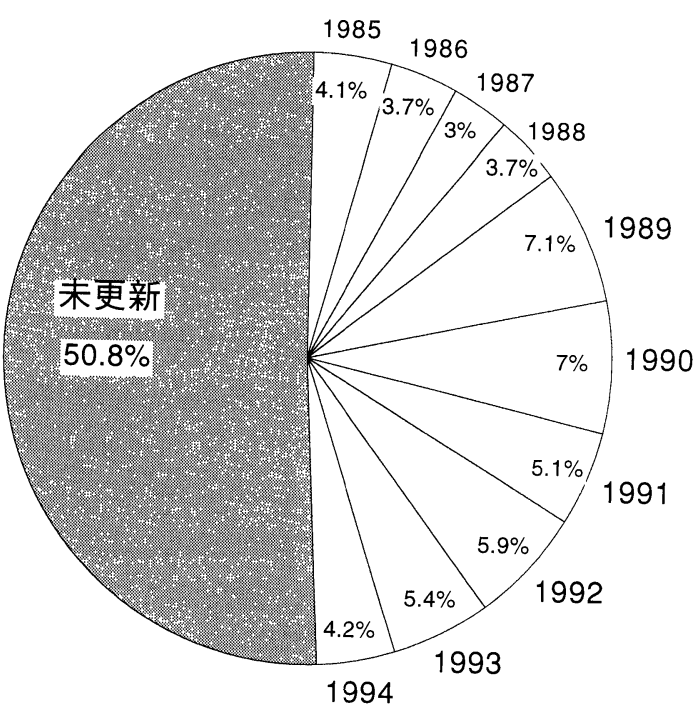

図 3 草地更新年次マップにおける各更新年次の面積割合 
について, 農家が正確な記録を残している例はまれで， 多くは農家の記憶に依存している。したがって，地上 デー夕の不確実性も否定できないため, このことが衛 星データで把握した更新年次と地上データが一致しな い原因と考えられる。

\section{（3）対象地域における草地更新の実態}

草地更新年次マップにおける更新年次別の草地面積 割合を図3に示した。それによれば，最近10年間に更新 されていない草地が全体の半分を占めるという解析結 果となった。対象地域においては, 地上調查や衛星デ一 夕の解析から, 年毎の更新率が7〜8\%という結果に なっている。年毎の高い更新率が示す通り, 草地更新 が頻繁に行われる草地が存在する一方で，10年以上の 長い期間にわたって，更新を行っていない草地が未だ に多く存在することを，この結果は示唆している。

また，草地更新の実態に関して，地域的な特徵を検 討した。対象地域のうち,マップの中央部の右側に相 当する計根別地区は，先進的な酪農経営を行っている 地区である。マップを見ると, 計根別周辺の草地では, 黄色や緑色の草地が多く分布し，1989年頃から，頻繁 に草地更新が行われた現状が把握できる。一方，その 他の地域では, 青色の草地が多く, 計根別地区より数 年遅れて，1992年頃から草地更新を頻繁に実施したの が判る。

以上のように, 地上調査により得ることが難しい草 地更新の空間分布に関する情報が, 衛星リモートセン シングにより観測することができた。

\section{（4）総合考察}

地上調査による草地更新状況の把握では, 聞き取り 調査が中心となるため，その空間分布に関する情報を 得ることには多大な労力を要する。一方，衛星リモー トセンシングによる草地更新の検出では, 広域の草地 更新状況が効率的に把握でき，その空間分布に関する 情報が得やすい。その反面, デー夕取得が天候や雲の 状況に依存するため, 年次によっては, 必ずしも草地 更新を十分に探知できない。しかしながら, 日本の ADEOS や米国の EOS 等の地球観測衛星計画があり, デー夕取得回数は増大することが期待できる。

本研究の対象の中心となる更新草地は特徵が明確で あり, 衛星デ一夕からの抽出が比較的容易なこと, 解 析の結果, 衛星デー夕取得に著しい制限がある年次以
外は，対象地域内でほぼ一定の更新率となったこと， 更新年次の精度に関して, 地上デ一夕と良く一致した こと等から考えて, 本研究により, 衛星りモートセン シングが草地更新状況を把握する有効な手法であるこ とが示されたと言える。

\section{5. ま と め}

本研究では, 多年次衛星デー夕から, 明確な特徵を 持つ更新草地，新播草地を抽出することにより北海道 根釧地域の1985 1994年までの草地更新年次マップを 作成した。その結果，対象地域内では，地上調査によ り把握されているのとほぼ同様の割合で草地更新が行 われている現状が捉えられた。

作成した草地更新年次マップを利用すれば，広域に わたる草地更新年次が把握でき, 本研究成果は, 草地 酪農に直接, 貢献できるものである。また, これらの デー夕は，デジタルマップであるため，他の情報との 重ね合わせが容易である。そのため, 衛星デ一夕から 得た草地の情報や既存の酪農関連情報との複合利用 等, 多様な利用が考えられる。

謝辞

前北海道立農業試験場土壌肥料科能代昌雄科長, な らびに科員, 同試験場作物科中島和彦研究員, 麻布大 学川鍋祐夫客員教授には地上デー夕の提供, および適 切な助言を得た。デー夕解析においては, 筑波大学環 境科学研究科平野聡氏の協力を賜った。本研究で使用 した衛星データの一部は, 宇宙開発事業団から研究向 けデー夕配布により提供を受けたものである。また, JERS-1/SAR データは, 資源・環境観測解析センター と農業環境技術研究所の共同研究の一環として, 同セ ンターより提供を受けた。ここに記して感謝する。 (受付日1996.1.24, 受理日1996.5.14)

\section{参考文献}

1) 秋山 㑆. ランドサットMSS データによる地表被覆 物の解析. 草地試研報, Vol. 17, pp.45-59, 1980 .

2) 秋山 㑆・安田嘉純・江森康文.リモート・センシン グによる草地の診断1. ランドサットMSSデータによる栃 木県北部の土地利用分類. 日本草地学会誌, Vol. 31 , pp. 88-96, 1985.

3 ) 秋山 㑆·安田嘉純·江森康文・深山一弥. リモート・ 
センシングによる草地の診断2. ランドサット MSS データ による一番草収量の推定. 日本草地学会誌, Vol. 31, pp. 97-103, 1985.

4) Akiyama, T., Y. Yamagata, M.Shibayama, H. HAYASHi and H.Fujita. Monitoring of weed infestation of grasslands using Landsat data.Proc. XVI Int. Grassl. Congr . pp.1389-1390, 1989.

5 ）秋山㑆. 草地とリモートセンシング1. 衛星搭 載センサーによる草原・草地植生の地球規模的観測.

日本草地学会誌, Vol. 37, pp.475-481, 1992.

6 ) 秋山 㑆. 草地とリモートセンシング2. 衛星情報 による草地・飼料畑の管理. 日本草地学会誌, Vol. 38, pp. 343-349, 1992.

7 ) 秋山 㑆. 衛星リモートセンシング技術の農業利 用研究 一広域的作物資源の分布と生育状態の定量的 把握一 生物環境調節, Vol. 32, pp.145-154, 1994 8 ) 片山正孝. 根室の草地紹介. 草・その情報, Vol.85, pp.21-25, 1994.

$9)$ Lopes, A. ,E. Nezry, R. Touzi and H. Laur. Structure detection and statistical speckle filtering in SAR images, Int.J.Remote Sensing, Vol.14, No.9,pp.1735-1758, 1993 .

10）美濃伸之・斎藤元也. 衛星デー夕による草地の経 年化に伴う分光反射特性変化の把握. 写真測量とリ モートセンシング，（印刷中）

11）山脇由紀代 · 斎藤元也 - 前野休明 - 福原道一 - 安 田嘉純・江森康文.ランドサット TM デー夕による草 地を中心とした地表被覆分類 - 階層性ツリ一構造に よる分類 - . 草地試研報, Vol. 39, pp.1-13, 1988. 